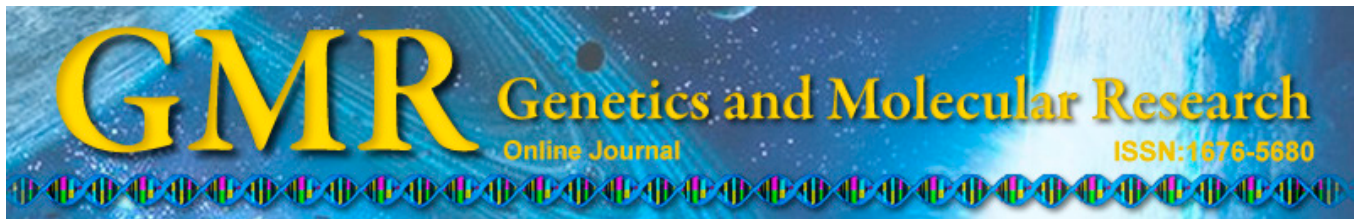

\title{
Associations between tumor necrosis factor- $\alpha$ polymorphisms and susceptibility to pulmonary tuberculosis: meta-analysis
}

\author{
Y.H. Lee and G.G. Song \\ Division of Rheumatology, Department of Internal Medicine, \\ Korea University College of Medicine, Seoul, Korea \\ Corresponding author: Y.H. Lee \\ E-mail: lyhcgh@korea.ac.kr
}

Genet. Mol. Res. 14 (3): 8602-8612 (2015)

Received September 3, 2014

Accepted April 6, 2015

Published July 31, 2015

DOI http://dx.doi.org/10.4238/2015.July.31.8

\begin{abstract}
The aim of this study was to determine whether tumor necrosis factor- $\alpha(T N F-\alpha)$ polymorphisms are associated with susceptibility to pulmonary tuberculosis (PTB) in different ethnic populations. MEDLINE and Embase databases and manual searches were employed to identify articles in which $T N F-\alpha$ polymorphisms were determined in patients with PTB and controls. A meta-analysis was conducted on the associations of the $T N F-\alpha-308 \mathrm{~A} / \mathrm{G},-238 \mathrm{~A} / \mathrm{G}$, and $-857 \mathrm{~T} / \mathrm{C}$ polymorphisms with PTB susceptibility. A total of 13 studies met the inclusion criteria, including 12, 6, and 4 studies on $T N F-\alpha$ $-308 \mathrm{~A} / \mathrm{G},-238 \mathrm{~A} / \mathrm{G}$, and $-857 \mathrm{~T} / \mathrm{C}$ polymorphisms, respectively. Metaanalysis showed no association between the $T N F-\alpha-308 \mathrm{~A}$ allele and PTB susceptibility in all study subjects (odds ratio, $\mathrm{OR}=1.182,95 \% \mathrm{CI}$ $=0.989-1.411, \mathrm{P}=0.066)$. After stratification by ethnicity, $T N F-\alpha$ -308A was not found to be associated with PTB in the European, Asian, or Middle East populations. No association was identified between PTB susceptibility and the $T N F-\alpha-238$ A allele in all study subjects $(\mathrm{OR}=1.031,95 \% \mathrm{CI}=0.741-1.436, \mathrm{P}=0.855)$, or in the European and Asian populations. However, $T N F-\alpha-857 \mathrm{~T}$ was significantly associated
\end{abstract}


with PTB susceptibility specifically in Asians $(\mathrm{OR}=0.682,95 \% \mathrm{CI}=$ $0.550-0.846, \mathrm{P}=4.8 \times 10^{-5}$ ). Meta-analysis using the dominant model, recessive model, or homozygote contrast showed the same pattern of results as for the $T N F-\alpha-857 \mathrm{~T}$ allele. Overall, no correlation was noted between the $T N F-\alpha-308 \mathrm{~A} / \mathrm{G}$ and $-238 \mathrm{~A} / \mathrm{G}$ polymorphisms and PTB susceptibility. However, the $T N F-\alpha-857 \mathrm{~T} / \mathrm{C}$ polymorphism was found to be associated with PTB susceptibility in the Asian population.

Key words: Tumor necrosis factor; Polymorphism; Meta-analysis; Pulmonary tuberculosis

\section{INTRODUCTION}

Tuberculosis is caused by the bacterium Mycobacterium tuberculosis, and affects several organs and frequently attacks the lungs. Pulmonary tuberculosis (PTB) is a common global infection. PTB is a granulomatous disease of the lungs, with high mortality and morbidity, especially in developing countries (Lawn and Zumla, 2011). Susceptibility to PTB is influenced by the genetic background of the host (Bellamy, 2003). Approximately $10 \%$ of the patients infected with $M$. tuberculosis have been reported to progress to the clinical stage of the disease (Comstock, 1982).

Tumor necrosis factor- $\alpha$ (TNF- $\alpha)$ is a potent proinflammatory cytokine that plays an important role in inflammatory and immune responses, including those observed in PTB (Rooney et al., 1995; Flynn and Chan, 2001). TNF- $\alpha$ stimulates cytokine production, which enhances the expression of adhesion molecules and increases neutrophil activation. TNF- $\alpha$ contributes to the pathogenesis of PTB by playing an important role in the formation of granulomas and by activating macrophages for disease perpetuation (Flynn and Chan, 2001). The TNF gene is located on chromosome 6, within the class III region of the human leukocyte antigen locus, and several single nucleotide polymorphisms have been identified in the $T N F$ promoter (Allen, 1999). TNF- $\alpha-308 \mathrm{~A} / \mathrm{G}$ (rs1800629), -238A/G (rs361525), and -857T/C (rs1799724) polymorphisms are the most commonly studied polymorphisms in PTB. This allelic variation has been proposed to be of functional significance (D'Alfonso and Richiardi, 1994; Kesarwani et al., 2009), although published findings are inconsistent (Wilson et al., 1997).

Several studies have examined the potential contribution of $T N F-\alpha$ promoter polymorphisms to PTB susceptibility, but the findings of these studies are also inconsistent (Selvaraj et al., 2001; Scola et al., 2003; Correa et al., 2004; Amirzargar et al., 2006; Oh et al., 2007; Vejbaesya et al., 2007; Ates et al., 2008; Merza et al., 2009; Trajkov et al., 2009; Ma et al., 2010; Sharma et al., 2010; Ben-Selma et al., 2011; Varahram et al., 2014). Individual studies based on small sample sizes have insufficient statistical power to detect positive associations and are incapable of demonstrating the absence of an association. Furthermore, the contradictions in the published results can likely be attributed to the low statistical power of the individual studies. On the other hand, a meta-analysis integrates previous research and increases the statistical power and resolution by pooling the results of independent analyses (Lee et al., 2007a,b, 2010, 2012). In the present study, we explored whether the $T N F-\alpha-308 \mathrm{~A} / \mathrm{G}$, $-238 \mathrm{~A} / \mathrm{G}$, and $-857 \mathrm{~T} / \mathrm{C}$ polymorphisms are associated with susceptibility to PTB by using a meta-analysis approach. 


\section{MATERIAL AND METHODS}

\section{Identification of eligible studies and data extraction}

A literature search was conducted to identify studies that examined the associations between $T N F-\alpha$ polymorphisms and PTB susceptibility. MEDLINE and Embase citation indexes were used to identify articles dated through April 2014 in which the $T N F-\alpha-308 \mathrm{~A} / \mathrm{G}$, $-238 \mathrm{~A} / \mathrm{G}$, and $-857 \mathrm{~T} / \mathrm{C}$ polymorphisms were identified in patients with PTB and controls. Combinations of key words such as "TNF- $\alpha$ ", "polymorphism", and "pulmonary tuberculosis" were entered as both Medical Subject Headings and text words. In addition, all references were reviewed to identify additional studies not indexed by MEDLINE and Embase. The inclusion criteria for studies of the analysis were as follows: i) case-control studies; ii) inclusion of patients with PTB; iii) inclusion of genotype data for the TNF- $\alpha$ polymorphisms; and iv) published in the English language. The exclusion criteria were as follows: i) presence of overlapping data; ii) unascertained genotypes; iii) inclusion of family members and consideration of familial linkages; and iv) inconsistent genotype distribution in controls with respect to the Hardy-Weinberg equilibrium (HWE), which suggests the possibility of biased control selection or genotyping errors. Information on the methods and results of the analyses was extracted from the original studies by two independent researchers. Disagreements were resolved by mutual consensus or by a third researcher. The following information was extracted from each study: author, year of publication, ethnicity based on the continent of origin of the study population, numbers of patients and controls, and the genotype and allele frequencies of the TNF- $\alpha$ polymorphisms.

\section{Evaluation of statistical associations}

The chi-square test was used to determine whether the observed genotype frequencies conformed to HWE. Meta-analyses were performed using the following: i) allelic contrast, ii) homozygote contrast, iii) recessive model, and iv) dominant model. Subgroup analyses were performed by ethnicity. The point estimates of odds ratios (ORs) and their $95 \%$ confidence intervals (CIs) were determined for each study. Cochran's Q-statistics were used to assess the within- and between-study variations and heterogeneities (Higgins and Thompson, 2002). The heterogeneity test was used to assess the null hypothesis that all studies evaluated the same effect. When a significant Q-statistic $(\mathrm{P}<0.10)$ indicated heterogeneity across studies, the random-effect model was used for the meta-analysis. When heterogeneity across studies was not indicated, the fixed-effect model was used. The fixed-effect meta-analysis assumes that genetic factors have similar effect on PTB susceptibility across all studies and that the observed variations between studies are caused by chance alone (Egger et al., 1997b). The random-effect model assumes that different studies show substantial diversity, and it assesses both the within-study sampling errors and between-study variances (DerSimonian and Laird, 1986). We quantified the effect of heterogeneity by using $I^{2}=100 \% \mathrm{x}(Q-d . f$.) / $Q$ (Higgins and Thompson, 2002). $I^{2}$ ranging between 0 and $100 \%$ represents the proportion of inter-study variability that can be attributed to the heterogeneity rather than to chance. $I^{2}$ values of 25,50 , and $75 \%$ were considered as low, moderate, and high, respectively. Statistical manipulations were performed using the Comprehensive Meta-Analysis software (Biostat, Englewood, NJ, USA). The powers of the studies were computed as the probabilities of detecting associations 
between $T N F-\alpha$ polymorphisms and PTB at a significance level of 0.05 , assuming small effect size convention $(w=0.10)$. Power analysis was performed using the $\mathrm{G}^{*}$ Power statistical software (http://www.psycho.uni-duesseldorf.de/aap/projects/gpower).

\section{Evaluation of publication bias}

Although funnel plots are often used to detect publication bias, funnel plotting requires a range of studies with varying sizes and involves subjective judgments. Accordingly, we evaluated the publication bias by using the Egger linear regression test (Egger et al., 1997a), which measures funnel plot asymmetry using a natural logarithm scale of ORs.

\section{RESULTS}

\section{Studies included in the meta-analysis}

In total, 72 studies were identified after electronic and manual searches, of which 23 were selected for a full-text review based on the title and abstract details. Ten studies were excluded because they did not contain extractable genotype data, were reviews, and other forms of tuberculosis; contained duplicate data or inconsistent genotype distributions in controls with respect to HWE; or were not published in the English language. Finally, 13 studies met the study inclusion criteria (Selvaraj et al., 2001; Scola et al., 2003; Correa et al., 2004; Amirzargar et al., 2006; Oh et al., 2007; Vejbaesya et al., 2007; Ates et al., 2008; Merza et al., 2009; Trajkov et al., 2009; Ma et al., 2010; Sharma et al., 2010; Ben-Selma et al., 2011; Varahram et al., 2014) (Figure 1), of which 12 studies examined $T N F-\alpha-308 \mathrm{~A} / \mathrm{G}, 6$ examined $-238 \mathrm{~A} / \mathrm{G}$, and 4 examined $-857 \mathrm{~T} / \mathrm{C}$ polymorphisms. The studies on the $T N F-\alpha-308 \mathrm{~A} / \mathrm{G}$ polymorphism involved 1751 patients with PTB and 1530 controls from four Asian, three European, three Middle Eastern, one African, and one South American population groups (Table 1). The studies on the $T N F-\alpha-238 \mathrm{~A} / \mathrm{G}$ polymorphism involved 864 patients with PTB and 863 controls from three Asian, two European, and one Middle Eastern population groups. The studies on the $T N F-\alpha-857 \mathrm{~T} / \mathrm{C}$ polymorphism involved 996 patients with PTB and 842 controls from two Asian, one European, and one Middle Eastern population groups (Table 1). Because the sample population in the African and South American studies was small, the ethnicity-specific meta-analysis was conducted on the European, Asian, and Middle Eastern populations. Selected characteristics of the relationships found between the $T N F-\alpha$ polymorphisms and PTB are summarized in Table 1. The statistical powers of these studies ranged from 24.2 to $90.9 \%$, and a single study had statistical power of $>80 \%$ (Ma et al., 2010).

\section{Meta-analysis of the association between the $T N F-\alpha-308 \mathrm{~A} / \mathrm{G}$ polymorphism and PTB susceptibility}

The meta-analysis showed no association between the $T N F-\alpha-308 \mathrm{~A}$ allele and PTB susceptibility in all study subjects $(\mathrm{OR}=1.182,95 \% \mathrm{CI}=0.989-1.411, \mathrm{P}=0.066)$ (Table 2 and Figure 2). After stratification by ethnicity, the meta-analysis indicated that the TNF- $\alpha-308 \mathrm{~A}$ allele was not associated with PTB susceptibility in the European, Asian, and Middle Eastern populations (Table 2 and Figure 2). The meta-analysis using the dominant model, recessive model, or homozygote contrast showed the same pattern of results as for the TNF- $\alpha-308 \mathrm{~A}$ allele (Table 2). 

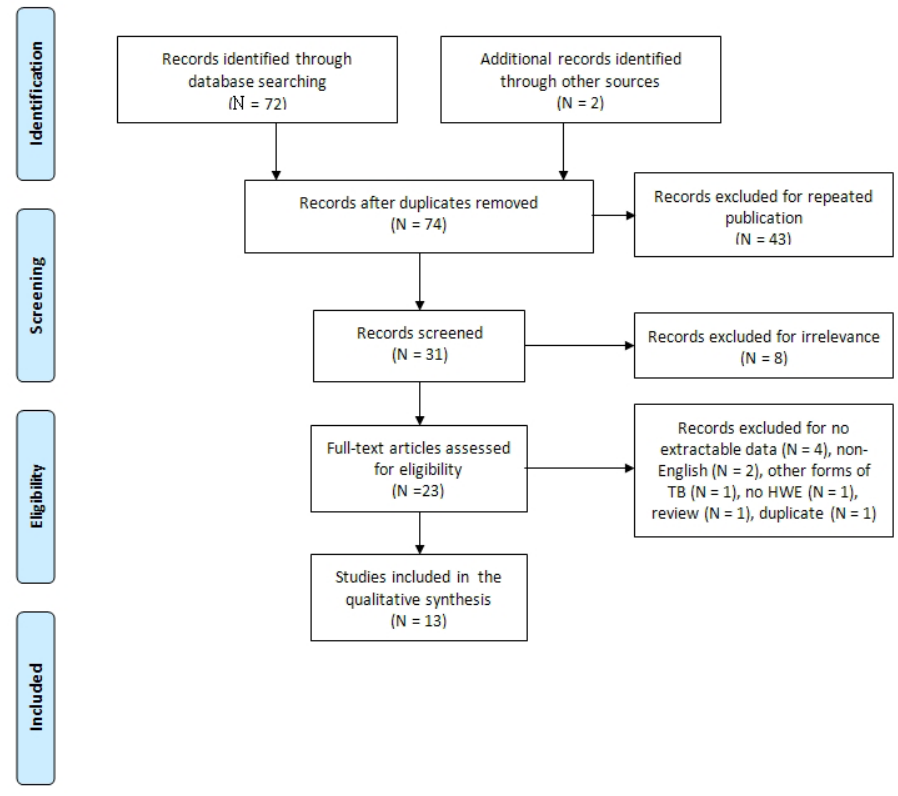

Figure 1. Flow chart study. TB = tuberculosis; HWE = Hardy-Weinberg equilibrium.

Table 1. Characteristics of the studies included in the meta-analysis.

\begin{tabular}{|c|c|c|c|c|c|c|c|c|c|c|c|c|c|}
\hline \multirow[t]{2}{*}{ Study } & \multirow[t]{2}{*}{ Country } & \multirow[t]{2}{*}{ Ethnicity } & \multirow[t]{2}{*}{ Polymorphism } & \multicolumn{2}{|c|}{ Number of individuals } & \multicolumn{3}{|c|}{$\begin{array}{l}\text { Patients with } \\
\text { tuberculosis }\end{array}$} & \multicolumn{3}{|c|}{ Controls } & \multirow[t]{2}{*}{$\begin{array}{l}\mathrm{P} \text { value for } \\
\text { association* }\end{array}$} & \multirow[t]{2}{*}{$\begin{array}{l}\text { Power } \\
(\%)^{* *}\end{array}$} \\
\hline & & & & Patients & Controls & 11 & 12 & 22 & 11 & 12 & 22 & & \\
\hline & & & TNF $-308 \mathrm{~A} / \mathrm{G}$ & & & GG & GA & AA & GG & GA & $\mathrm{AA}$ & & \\
\hline Varahram et al., 2014 & Iran & Middle Eastern & $-308 \mathrm{~A} / \mathrm{G}$ & 151 & 83 & 122 & 28 & 1 & 71 & 12 & 0 & 0.329 & 33.3 \\
\hline Ben-Selma et al., 2011 & Tunisia & African & $-308 \mathrm{~A} / \mathrm{G}$ & 76 & 95 & 52 & 21 & 3 & 70 & 23 & 2 & 0.371 & 25.7 \\
\hline Sharma et al., 2010 & India & Asian & $-308 \mathrm{~A} / \mathrm{G}$ & 185 & 155 & 152 & 30 & 3 & 130 & 23 & 2 & 0.648 & 45.3 \\
\hline Trajkov et al., 2009 & Macedonia & European & $-308 \mathrm{~A} / \mathrm{G}$ & 75 & 301 & 62 & 11 & 2 & 231 & 66 & 4 & 0.438 & 49.1 \\
\hline Merza et al., 2009 & Sweden & European & $-308 \mathrm{~A} / \mathrm{G}$ & 117 & 60 & 90 & 24 & 3 & 56 & 4 & 0 & 0.008 & 26.4 \\
\hline Ates et al., 2008 & Turkey & Middle Eastern & $-308 \mathrm{~A} / \mathrm{G}$ & 128 & 80 & 108 & 20 & 0 & 66 & 14 & 0 & 0.734 & 31.2 \\
\hline Oh et al., 2007 & Korea & Asian & $-308 \mathrm{~A} / \mathrm{G}$ & 145 & 117 & 105 & 37 & 3 & 81 & 35 & 1 & 0.755 & 36.6 \\
\hline Vejbaesya et al., 2007 & Thailand & Asian & $-308 \mathrm{~A} / \mathrm{G}$ & 149 & 147 & 123 & 26 & 0 & 128 & 17 & 2 & 0.477 & 40.5 \\
\hline Amirzargar et al., 2006 & Iran & Middle Eastern & $-308 \mathrm{~A} / \mathrm{G}$ & 40 & 123 & 32 & 8 & 0 & 89 & 33 & 1 & 0.334 & 24.7 \\
\hline Correa et al., 2004 & Colombia & South American & $-308 \mathrm{~A} / \mathrm{G}$ & 430 & 135 & 338 & 87 & 5 & 118 & 16 & 1 & 0.031 & 66.1 \\
\hline Scola et al., 2003 & Italy & European & $-308 \mathrm{~A} / \mathrm{G}$ & 45 & 114 & 27 & 17 & 1 & 88 & 24 & 2 & 0.048 & 24.2 \\
\hline \multirow[t]{2}{*}{ Selvaraj et al., 2001} & India & Asian & $-308 \mathrm{~A} / \mathrm{G}$ & 210 & 120 & 185 & 24 & 1 & 103 & 17 & 0 & 0.655 & 44.3 \\
\hline & & & TNF $-238 \mathrm{~A} / \mathrm{G}$ & & & GG & GA & AA & GG & GA & AA & & \\
\hline Sharma et al., 2010 & India & Asian & $-238 \mathrm{~A} / \mathrm{G}$ & 185 & 155 & 164 & 19 & 2 & 141 & 14 & 0 & 0.332 & 45.3 \\
\hline Trajkov et al., 2009 & Macedonia & European & $-238 \mathrm{~A} / \mathrm{G}$ & 75 & 301 & 70 & 5 & 0 & 276 & 23 & 2 & 0.533 & 49.1 \\
\hline Merza et al., 2009 & Sweden & European & $-238 \mathrm{~A} / \mathrm{G}$ & 117 & 60 & 108 & 9 & 0 & 57 & 3 & 0 & 0.511 & 26.4 \\
\hline Ates et al., 2008 & Turkey & Middle Eastern & $-238 \mathrm{~A} / \mathrm{G}$ & 128 & 80 & 121 & 7 & 0 & 77 & 3 & 0 & 0.580 & 30.2 \\
\hline Vejbaesya et al., 2007 & Thailand & Asian & $-238 \mathrm{~A} / \mathrm{G}$ & 149 & 147 & 136 & 13 & 0 & 137 & 10 & 0 & 0.546 & 40.5 \\
\hline \multirow[t]{2}{*}{ Amirzargar et al., 2006} & India & Asian & $-238 \mathrm{~A} / \mathrm{G}$ & 210 & 120 & 176 & 34 & 0 & 96 & 23 & 1 & 0.316 & 44.3 \\
\hline & & & TNF $-857 \mathrm{~T} / \mathrm{C}$ & & & $\mathrm{CC}$ & $\mathrm{CT}$ & TT & $\mathrm{CC}$ & $\mathrm{CT}$ & $\mathrm{TT}$ & & \\
\hline Varahram et al., 2014 & Iran & Middle Eastern & $-857 \mathrm{~T} / \mathrm{C}$ & 151 & 83 & 85 & 60 & 6 & 35 & 40 & 8 & 0.022 & 33.3 \\
\hline Ma et al., 2010 & China & Asian & $-857 \mathrm{~T} / \mathrm{C}$ & 543 & 544 & 409 & 131 & 3 & 371 & 153 & 20 & 0.001 & 90.9 \\
\hline Sharma et al., 2010 & India & Asian & $-857 \mathrm{~T} / \mathrm{C}$ & 185 & 155 & 154 & 31 & 0 & 123 & 30 & 2 & 0.254 & 45.3 \\
\hline Merza et al., 2009 & Sweden & European & $-857 \mathrm{~T} / \mathrm{C}$ & 117 & 60 & 69 & 42 & 6 & 42 & 18 & 0 & 0.076 & 26.4 \\
\hline
\end{tabular}

*Allele contrast: allele 2 vs 1 ; **power calculations assume $\alpha=0.05$, small effect size convention $(\mathrm{w}=0.10)$; apulmonary tuberculosis (PTB; $\mathrm{N}=149)$; ${ }^{\mathrm{b}} \mathrm{PTB}(\mathrm{N}=98)$. 
Table 2. Meta-analysis of the association between the $T N F-\alpha-308 \mathrm{~A} / \mathrm{G}$ polymorphism and PTB susceptibility.

\begin{tabular}{|c|c|c|c|c|c|c|c|c|c|c|}
\hline \multirow[t]{2}{*}{ Polymorphism } & \multirow[t]{2}{*}{ Population } & \multirow[t]{2}{*}{ No. of studies } & \multicolumn{2}{|c|}{ Subject No. } & \multicolumn{3}{|c|}{ Test of association } & \multicolumn{3}{|c|}{ Test of heterogeneity } \\
\hline & & & Patients & Controls & OR & $95 \% \mathrm{CI}$ & $P$ value & Model & $P$ value & $\mathrm{I}^{2}$ \\
\hline \multirow[t]{4}{*}{$T N F-\alpha-308 \mathrm{~A}$ vs $\mathrm{G}$ allele } & Overall & 12 & 1751 & 1530 & 1.182 & $0.989-1.411$ & 0.066 & $\mathrm{~F}$ & 0.117 & 34.0 \\
\hline & European & 3 & 237 & 475 & 1.712 & $0.706-4.152$ & 0.234 & $\mathrm{R}$ & 0.013 & 76.9 \\
\hline & Asian & 4 & 689 & 539 & 1.027 & $0.781-1.351$ & 0.848 & $\mathrm{~F}$ & 0.808 & 0 \\
\hline & Middle Eastern & 3 & 319 & 286 & 0.976 & $0.638-1.493$ & 0.910 & $\mathrm{~F}$ & 0.370 & 0 \\
\hline \multirow[t]{4}{*}{$\mathrm{AA}+\mathrm{AG} v s \mathrm{GG}$ (Dominant) } & Overall & 12 & 1751 & 1530 & 1.198 & $0.923-1.550$ & 0.171 & $\mathrm{R}$ & 0.063 & 41.8 \\
\hline & European & 3 & 237 & 475 & 1.756 & $0.621-4.965$ & 0.288 & $\mathrm{R}$ & 0.007 & 79.7 \\
\hline & Asian & 4 & 689 & 539 & 1.021 & $0.758-1.376$ & 0.889 & $\mathrm{~F}$ & 0.574 & 0 \\
\hline & Middle Eastern & 3 & 319 & 286 & 0.966 & $0.617-1.514$ & 0.882 & F & 0.397 & 0 \\
\hline \multirow[t]{4}{*}{ AA $v s$ AG+GG (Recessive) } & Overall & 11 & 1632 & 1450 & 1.551 & $0.770-3.123$ & 0.219 & $\mathrm{~F}$ & 0.990 & 0 \\
\hline & European & 3 & 237 & 475 & 1.994 & $0.561-7.087$ & 0.286 & $\mathrm{~F}$ & 0.862 & 0 \\
\hline & Asian & 4 & 689 & 539 & 1.187 & $0.316-3.902$ & 0.778 & $\mathrm{~F}$ & 0.615 & 0 \\
\hline & Middle Eastern & 2 & 191 & 206 & 1.296 & $0.133-12.59$ & 0.823 & F & 0.829 & 0 \\
\hline \multirow[t]{4}{*}{ AA $v s$ GG } & Overall & 11 & 1632 & 1450 & 1.599 & $0.793-3.226$ & 0.190 & $\mathrm{~F}$ & 0.990 & 0 \\
\hline & European & 3 & 237 & 475 & 2.098 & $0.588-7.481$ & 0.253 & $\mathrm{~F}$ & 0.864 & 0 \\
\hline & Asian & 4 & 689 & 539 & 1.183 & $0.359-3.897$ & 0.782 & F & 0.651 & 0 \\
\hline & Middle Eastern & 2 & 191 & 206 & 1.269 & $0.130-12.36$ & 0.837 & $\mathrm{~F}$ & 0.781 & 0 \\
\hline
\end{tabular}

$\mathrm{PTB}=$ pulmonary tuberculosis; $\mathrm{OR}=$ odds ratio; $\mathrm{CI}=$ confidence interval; $\mathrm{F}=$ fixed-effect model; $\mathrm{R}=$ randomeffect model.
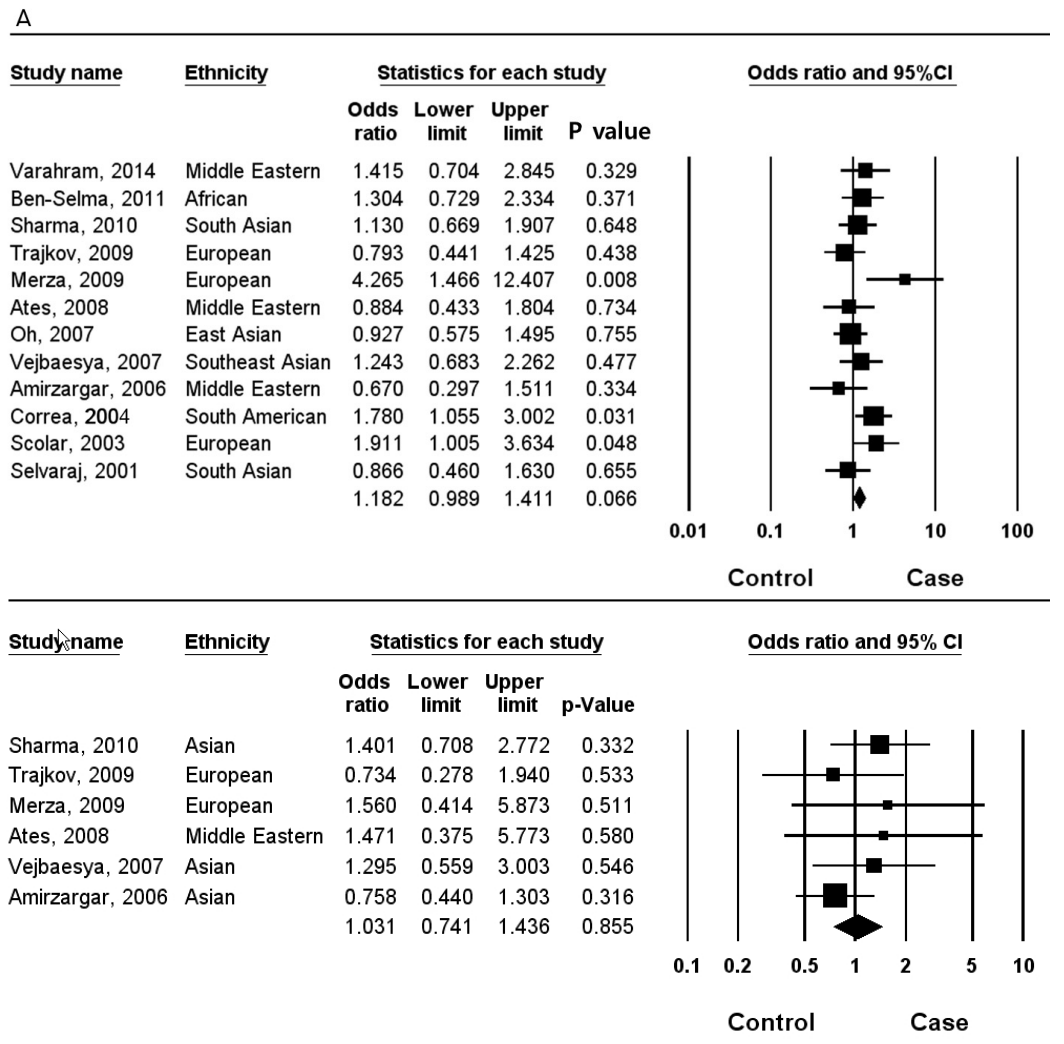

Figure 2. ORs and $95 \% \mathrm{CIs}$ from individual studies and pooled data for the association between the A allele of the $T N F-\alpha-308 \mathrm{~A} / \mathrm{G}(\mathbf{A})$ and $T N F-\alpha-238 \mathrm{~A} / \mathrm{G}(\mathbf{B})$ polymorphisms and PTB susceptibility in all subjects. OR = odds ratio; $\mathrm{CI}=$ confidence interval; $\mathrm{PTB}=$ pulmonary tuberculosis. The size of the boxes means the weight assigned to each study. 


\section{Meta-analysis of the association between the $T N F-\alpha-238 \mathrm{~A} / \mathrm{G}$ polymorphism and PTB susceptibility}

The meta-analysis of the $T N F-\alpha-238 \mathrm{~A} / \mathrm{G}$ polymorphism showed no association between PTB susceptibility and the $T N F-\alpha-238 \mathrm{~A}$ allele in all study subjects (OR $=1.031$, $95 \% \mathrm{CI}=0.741-1.436, \mathrm{P}=0.855$ ) (Table 3 and Figure 2 ). The ethnicity-specific meta-analysis indicated that the $T N F-\alpha-238 \mathrm{~A}$ allele was not associated with PTB susceptibility in the European and Asian populations (Table 3). Analysis using the dominant model, recessive model, and homozygote contrast showed the same pattern as for the TNF- $\alpha-238 \mathrm{~A}$ allele (Table 3).

\begin{tabular}{|c|c|c|c|c|c|c|c|c|c|c|}
\hline \multirow[t]{2}{*}{ Polymorphism } & \multirow[t]{2}{*}{ Population } & \multirow[t]{2}{*}{ No. of studies } & \multicolumn{2}{|c|}{ Subject No. } & \multicolumn{3}{|c|}{ Test of association } & \multicolumn{3}{|c|}{ Test of heterogeneity } \\
\hline & & & Patients & Controls & OR & $95 \% \mathrm{CI}$ & P value & Model & $P$ value & $\mathrm{I}^{2}$ \\
\hline \multirow[t]{3}{*}{$T N F-\alpha-238 \mathrm{~A} v s \mathrm{G}$ allele } & Overall & 6 & 864 & 863 & 1.031 & $0.741-1.436$ & 0.855 & $\mathrm{~F}$ & 0.638 & 0 \\
\hline & European & 2 & 192 & 361 & 0.956 & $0.436-2.092$ & 0.909 & $\mathrm{~F}$ & 0.369 & 0 \\
\hline & Asian & 3 & 544 & 422 & 1.022 & $0.699-1.492$ & 0.912 & $\mathrm{~F}$ & 0.317 & 12.9 \\
\hline \multirow[t]{3}{*}{$\mathrm{AA}+\mathrm{AG} v s \mathrm{GG}$ (Dominant) } & Overall & 6 & 864 & 863 & 1.039 & $0.736-1.467$ & 0.830 & $\mathrm{~F}$ & 0.767 & 0 \\
\hline & European & 2 & 192 & 361 & 1.009 & $0.453-2.246$ & 0.892 & $\mathrm{~F}$ & 0.414 & 0 \\
\hline & Asian & 3 & 544 & 422 & 1.016 & $0.682-1.512$ & 0.940 & $\mathrm{~F}$ & 0.444 & 0 \\
\hline \multirow[t]{3}{*}{ AA vs AG+GG (Recessive) } & Overall & 3 & 470 & 576 & 0.906 & $0.152-5.417$ & 0.914 & $\mathrm{~F}$ & 0.385 & 0 \\
\hline & European & 1 & 75 & 301 & 0.793 & $0.038-16.70$ & 0.882 & NA & NA & NA \\
\hline & Asian & 2 & 395 & 275 & 0.972 & $0.107-8.842$ & 0.980 & $\mathrm{~F}$ & 0.168 & 47.3 \\
\hline \multirow[t]{3}{*}{ AA $v s \mathrm{GG}$} & Overall & 3 & 470 & 576 & 0.897 & $0.150-5.365$ & 0.905 & $\mathrm{~F}$ & 0.373 & 0 \\
\hline & European & 1 & 75 & 301 & 0.784 & $0.037-16.52$ & 0.875 & NA & NA & NA \\
\hline & Asian & 2 & 395 & 275 & 0.963 & $0.106-8.766$ & 0.973 & $\mathrm{~F}$ & 0.161 & 49.0 \\
\hline \multirow[t]{2}{*}{$T N F-\alpha-857 \mathrm{~T} v s \mathrm{C}$ allele } & Overall & 4 & 996 & 842 & 0.802 & $0.557-1.154$ & 0.235 & $\mathrm{R}$ & 0.027 & 67.2 \\
\hline & Asian & 2 & 728 & 699 & 0.682 & $0.550-0.846$ & $4.8 \times 10^{-5}$ & $\mathrm{~F}$ & 0.720 & 0 \\
\hline \multirow[t]{2}{*}{$\mathrm{TT}+\mathrm{TC}$ vs CC (Dominant) } & Overall & 4 & 996 & 842 & 0.793 & $0.557-1.129$ & 0.199 & $\mathrm{R}$ & 0.091 & 53.6 \\
\hline & Asian & 2 & 728 & 699 & 0.716 & $0.563-0.909$ & 0.006 & $\mathrm{~F}$ & 0.756 & 0 \\
\hline \multirow[t]{2}{*}{$\mathrm{TT} v s \mathrm{TC}+\mathrm{CC}$ (Recessive) } & Overall & 4 & 996 & 842 & 0.370 & $0.104-1.319$ & 0.125 & $\mathrm{R}$ & 0.099 & 52.2 \\
\hline & Asian & 2 & 728 & 699 & 0.148 & $0.048-0.460$ & 0.001 & $\mathrm{~F}$ & 0.939 & 0 \\
\hline \multirow[t]{2}{*}{$\mathrm{TT} v s \mathrm{CC}$} & Overall & 4 & 996 & 842 & 0.341 & $0.091-1.277$ & 0.110 & $\mathrm{R}$ & 0.086 & 54.5 \\
\hline & Asian & 2 & 728 & 699 & 0.139 & $0.045-0.432$ & 0.001 & $\mathrm{~F}$ & 0.923 & 0 \\
\hline
\end{tabular}

$\mathrm{PTB}=$ pulmonary tuberculosis; $\mathrm{OR}=$ odds ratio; $\mathrm{CI}=$ confidence interval; $\mathrm{F}=$ fixed-effect model; $\mathrm{R}=$ randomeffect model; $\mathrm{NA}=$ not available.

\section{Meta-analysis of the association between the $T N F-\alpha-857 \mathrm{~T} / \mathrm{C}$ polymorphism and PTB susceptibility}

The meta-analysis showed no association between the $T N F-\alpha-857 \mathrm{~T}$ allele and PTB susceptibility in all study subjects $(\mathrm{OR}=0.802,95 \% \mathrm{CI}=0.557-1.154, \mathrm{P}=0.235)$ (Table 3$)$. After stratification by ethnicity, the meta-analysis indicated that the $T N F-\alpha-857$ T allele was significantly associated with PTB susceptibility in the Asian population $(\mathrm{OR}=0.682,95 \% \mathrm{CI}=0.550-0.846, \mathrm{P}$ $\left.=4.8 \times 10^{-5}\right)($ Table 3 and Figure 3$)$. The meta-analysis using the dominant model, recessive model, or homozygote contrast showed the same pattern of results as for the $T N F-\alpha-857 \mathrm{~T}$ allele (Table 3 ).

\section{Heterogeneity, subgroup analysis, and publication bias}

Between-study heterogeneity was observed in the meta-analyses of the TNF- $\alpha-857 \mathrm{~T} /$ C polymorphism and PTB susceptibility (Tables 2 and 3). When the group was stratified by 
ethnicity, the heterogeneity in the meta-analysis of the $T N F-\alpha-857 \mathrm{~T} / \mathrm{C}$ polymorphism was resolved. Subgroup analysis by exclusion of two studies containing other forms of tuberculosis did not significantly change the meta-analysis results (Ates et al., 2008; Sharma et al., 2010). The Egger regression test showed no evidence of publication bias in the meta-analysis of the $T N F-\alpha-308 \mathrm{~A} / \mathrm{G},-238 \mathrm{~A} / \mathrm{G}$, or $-857 \mathrm{~T} / \mathrm{C}$ polymorphisms $(\mathrm{P}>0.1$; Figure 4$)$.

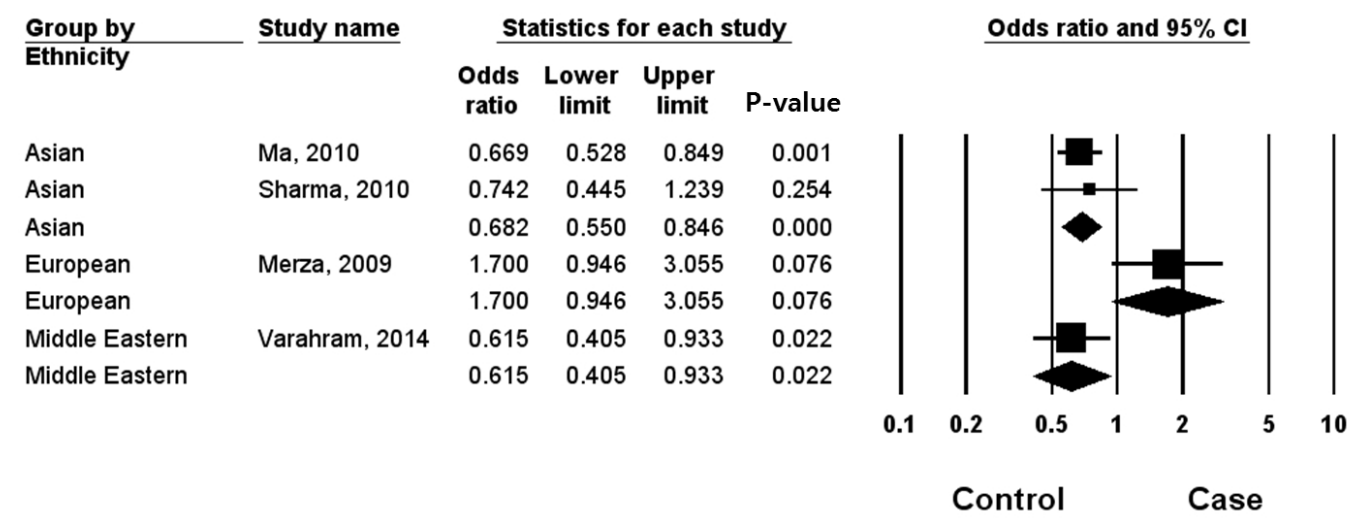

Figure 3. ORs and 95\%CIs from individual studies and pooled data for the allelic association between the $T N F-\alpha$ $-857 \mathrm{~T} / \mathrm{C}$ polymorphism and PTB susceptibility in each ethnic group. $\mathrm{OR}=$ odds ratio; $\mathrm{CI}=$ confidence interval; $\mathrm{PTB}=$ pulmonary tuberculosis. The size of the boxes means the weight assigned to each study.

\section{DISCUSSION}

The host immune response against $M$. tuberculosis is mediated by cellular immunity (Bellamy, 2003). TNF- $\alpha$ promotes phagocytosis of macrophages and stimulates apoptosis of macrophages, depriving the pathogenic bacilli of host cells (Rooney et al., 1995; Flynn and Chan, 2001). Use of a TNF- $\alpha$ inhibitor was shown to reactivate PTB in patients with rheumatoid arthritis (Keane, 2005) and mice deficient in TNF- $\alpha$ showed poorly formed granulomas, leading to widespread dissemination of M. tuberculosis (Bean et al., 1999). These findings suggest that TNF- $\alpha$ plays a key role in the formation and maintenance of granuloma in PTB.

The promoter of the $T N F-\alpha$ gene is highly polymorphic and has been considered a candidate region for PTB susceptibility. The present study addressed the association between $T N F-\alpha$ polymorphisms and PTB susceptibility. Data from published studies were assessed by meta-analysis to evaluate the genetic associations between the most commonly studied polymorphisms of the $T N F-\alpha$ gene: $T N F-\alpha-308 \mathrm{~A} / \mathrm{G},-238 \mathrm{~A} / \mathrm{G}$, and $-857 \mathrm{~T} / \mathrm{C}$, and PTB susceptibility. We found an association between PTB susceptibility and the TNF- $\alpha-857 \mathrm{~T} / \mathrm{C}$ polymorphism in the Asian population $\left(\mathrm{OR}=0.682,95 \% \mathrm{CI}=0.550-0.846, \mathrm{P}=4.8 \times 10^{-5}\right)$. Metaanalyses using the dominant model, recessive model, or homozygote contrast showed the same pattern of results as for the TNF- $\alpha-857 \mathrm{~T}$ allele.

Our meta-analysis indicated a significant association between the $T N F-\alpha-857 \mathrm{~T} / \mathrm{C}$ polymorphism and PTB susceptibility in Asians. Previous studies have shown that the TNF- $\alpha$ $-857 \mathrm{~T} / \mathrm{C}$ polymorphism might have functional significance (Kesarwani et al., 2009). The $T N F-\alpha-857 \mathrm{~T}$ allele of this polymorphism showed significantly greater transcriptional activity 
A

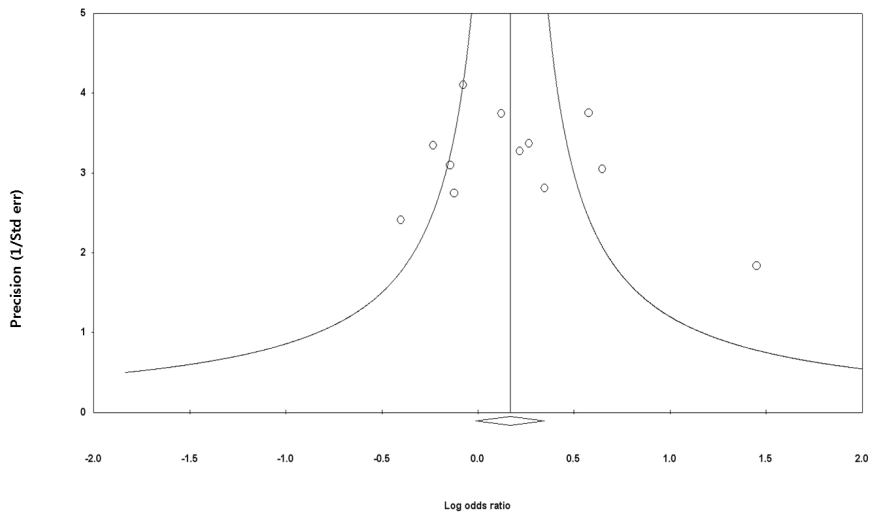

B

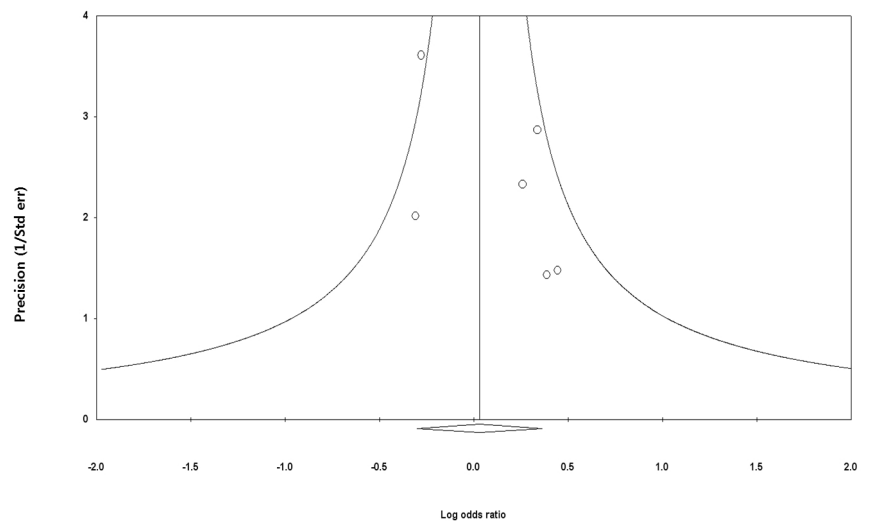

C

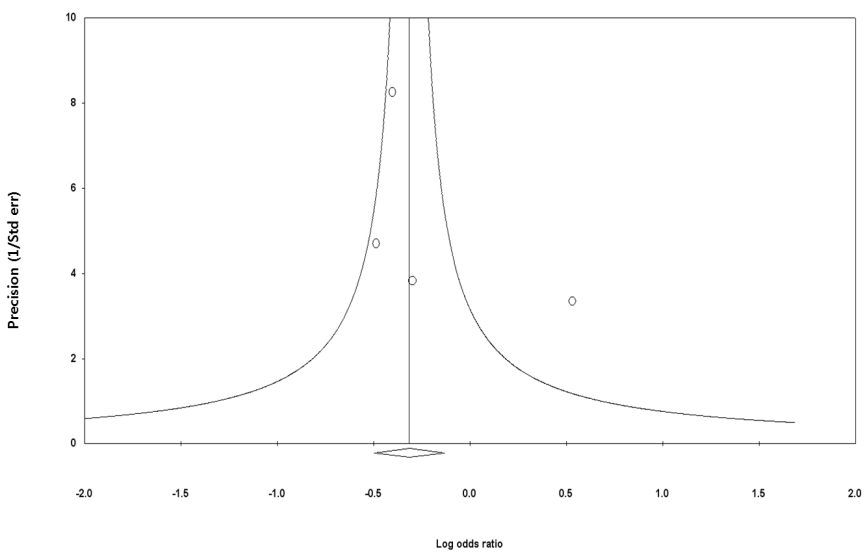

Figure 4. Funnel plot of the studies of the allelic association between $T N F-\alpha-308 \mathrm{~A} / \mathrm{G}(\mathbf{A}),-238 \mathrm{~A} / \mathrm{G}$ (B), and $-857 \mathrm{~T} / \mathrm{C}(\mathbf{C})$ polymorphisms and PTB susceptibility in all subjects (Egger's regression $\mathrm{P}>0.1$ ). $\mathrm{PTB}=$ pulmonary tuberculosis; Std err $=$ standard error. 
than did the $T N F-\alpha-857 \mathrm{C}$ allele in response to lipopolysaccharides (Kesarwani et al., 2009). This result suggests that the $-857 \mathrm{~T}$ allele of the $T N F-\alpha$ gene, which is associated with increased production of TNF- $\alpha$, might be associated with the formation and maintenance of granulomas in PTB, as TNF- $\alpha$ plays an important role in protective immunity against $M$. tuberculosis. The TNF- $\alpha-857 \mathrm{~T} / \mathrm{C}$ polymorphism has also been shown to be associated with a susceptibility to Grave's disease (Inoue et al., 2009). It remains to be clarified whether the association between the $T N F-\alpha-857 \mathrm{~T} / \mathrm{C}$ polymorphism and PTB susceptibility is present in other ethnic groups as well, such as European and Middle Eastern populations. Thus, further studies are needed to address this question. However, our study result should be interpreted with caution because only two studies on Asian populations were included.

Our meta-analysis failed to find an association between PTB susceptibility and the $T N F-\alpha-308 \mathrm{~A} / \mathrm{G}$ and $-238 \mathrm{~A} / \mathrm{G}$ polymorphisms in all subjects and in different populations. This might be explained by the existence of genetic heterogeneity for PTB between different populations as demonstrated in genetic association studies on PTB. Clinical heterogeneities and differences between patient populations might also be responsible for the lack of observed association. In addition, discrepancies might have been caused by different linkage disequilibrium (LD) patterns. For example, these polymorphisms might be in LD with a nearby causal variant in one ethnic group but not in another. Furthermore, the lack of identified association might be due to the small number of studies analyzed, low statistical power, or type II errors.

The present study has some limitations. First, publication bias, heterogeneity, and confounding factors might have distorted the meta-analysis. Second, this meta-analysis included data from European, Middle Eastern, and Asian patients; thus, our results are applicable to only these ethnic groups. Third, haplotype analysis could have provided more information and would have been more powerful than single polymorphism analysis. However, we could not use this approach because of inadequate haplotype data provided in the studies included. Fourth, it would have been interesting to examine associations among the TNF- $\alpha$ polymorphisms, disease activities, and clinical features, but limited or unavailable data hindered such an analysis.

In conclusion, this meta-analysis demonstrated that there was no association between $T N F-\alpha-308 \mathrm{~A} / \mathrm{G}$ or $-238 \mathrm{~A} / \mathrm{G}$ polymorphisms and PTB susceptibility in European, Asian, or Middle Eastern populations, but demonstrated an association of the TNF- $\alpha-857 \mathrm{~T} / \mathrm{C}$ polymorphism with PTB susceptibility in Asians. The role of $T N F-\alpha$ polymorphisms on the pathogenesis of PTB remains uncertain, but our data suggest that the $T N F-\alpha-857 \mathrm{~T} / \mathrm{C}$ polymorphism might contribute to PTB susceptibility in the Asian population. Thus, the role of $T N F-\alpha$ polymorphisms on the pathogenesis of PTB needs to be determined by studies with larger sample size from different ethnic groups.

\section{Conflicts of interest}

The authors declare no conflict of interest.

\section{REFERENCES}

Allen RD (1999). Polymorphism of the human TNF-alpha promoter - random variation or functional diversity? Mol. Immunol. 36: 1017-1027.

Amirzargar AA, Rezaei N, Jabbari H, Danesh AA, et al. (2006). Cytokine single nucleotide polymorphisms in Iranian patients with pulmonary tuberculosis. Eur. Cytokine Netw. 17: 84-89.

Ates O, Musellim B, Ongen G and Topal-Sarikaya A (2008). Interleukin-10 and tumor necrosis factor-alpha gene 
polymorphisms in tuberculosis. J. Clin. Immunol. 28: 232-236.

Bean AG, Roach DR, Briscoe H, France MP, et al. (1999). Structural deficiencies in granuloma formation in TNF genetargeted mice underlie the heightened susceptibility to aerosol Mycobacterium tuberculosis infection, which is not compensated for by lymphotoxin. J. Immunol. 162: 3504-3511.

Bellamy R (2003). Susceptibility to mycobacterial infections: the importance of host genetics. Genes Immun. 4: 4-11.

Ben-Selma W, Harizi H and Boukadida J (2011). Association of TNF-alpha and IL-10 polymorphisms with tuberculosis in Tunisian populations. Microbes Infect. 13: 837-843.

Comstock GW (1982). Epidemiology of tuberculosis. Am. Rev. Respir. Dis. 125: 8-15.

Correa PA, Gómez LM and Anaya JM (2004). Polymorphism of TNF-alpha in autoimmunity and tuberculosis. Biomedica 24: $43-51$.

D'Alfonso S and Richiardi PM (1994). A polymorphic variation in a putative regulation box of the TNFA promoter region. Immunogenetics 39: 150-154.

DerSimonian R and Laird N (1986). Meta-analysis in clinical trials. Control. Clin. Trials 7: 177-188.

Egger M, Davey Smith G, Schneider M and Minder C (1997a). Bias in meta-analysis detected by a simple, graphical test. BMJ 315: 629-634.

Egger M, Smith GD and Phillips AN (1997b). Meta-analysis: principles and procedures. BMJ 315: 1533-1537.

Flynn JL and Chan J (2001). Immunology of tuberculosis. Annu. Rev. Immunol. 19: 93-129.

Higgins JP and Thompson SG (2002). Quantifying heterogeneity in a meta-analysis. Stat. Med. 21: 1539-1558.

Inoue N, Watanabe M, Nanba T, Wada M, et al. (2009). Involvement of functional polymorphisms in the TNFA gene in the pathogenesis of autoimmune thyroid diseases and production of anti-thyrotropin receptor antibody. Clin. Exp. Immunol. 156: 199-204.

Keane J (2005). TNF-blocking agents and tuberculosis: new drugs illuminate an old topic. Rheumatology 44: 714-720.

Kesarwani P, Mandhani A and Mittal RD (2009). Polymorphisms in tumor necrosis factor-A gene and prostate cancer risk in North Indian cohort. J. Urol. 182: 2938-2943.

Lawn SD and Zumla AI (2011). Tuberculosis. Lancet 378: 57-72.

Lee YH, Rho YH, Choi SJ, Ji JD, et al. (2007a). PADI4 polymorphisms and rheumatoid arthritis susceptibility: a metaanalysis. Rheumatol. Int. 27: 827-833.

Lee YH, Rho YH, Choi SJ, Ji JD, et al. (2007b). The PTPN22 C1858T functional polymorphism and autoimmune diseases - a meta-analysis. Rheumatology 46: 49-56.

Lee YH, Woo JH, Choi SJ, Ji JD, et al. (2010). Associations between osteoprotegerin polymorphisms and bone mineral density: a meta-analysis. Mol. Biol. Rep. 37: 227-234.

Lee YH, Choi SJ, Ji JD and Song GG (2012). Candidate gene studies of fibromyalgia: a systematic review and metaanalysis. Rheumatol. Int. 32: 417-426.

Ma MJ, Xie LP, Wu SC, Tang F, et al. (2010). Toll-like receptors, tumor necrosis factor- $\alpha$, and interleukin-10 gene polymorphisms in risk of pulmonary tuberculosis and disease severity. Hum. Immunol. 71: 1005-1010.

Merza M, Farnia P, Anoosheh S, Varahram M, et al. (2009). The NRAMPI, VDR and TNF-alpha gene polymorphisms in Iranian tuberculosis patients: the study on host susceptibility. Braz. J. Infect. Dis. 13: 252-256.

Oh JH, Yang CS, Noh YK, Kweon YM, et al. (2007). Polymorphisms of interleukin-10 and tumour necrosis factor-alpha genes are associated with newly diagnosed and recurrent pulmonary tuberculosis. Respirology 12: 594-598.

Rooney M, David J, Symons J, Di Giovine F, et al. (1995). Inflammatory cytokine responses in juvenile chronic arthritis. Br. J. Rheumatol. 34: 454-460.

Scola L, Crivello A, Marino V, Gioia V, et al. (2003). IL-10 and TNF-alpha polymorphisms in a sample of Sicilian patients affected by tuberculosis: implication for ageing and life span expectancy. Mech. Ageing Dev. 124: 569-572.

Selvaraj P, Sriram U, Mathan Kurian S, Reetha AM, et al. (2001). Tumour necrosis factor alpha (-238 and -308) and beta gene polymorphisms in pulmonary tuberculosis: haplotype analysis with HLA-A, B and DR genes. Tuberculosis 81: 335-341.

Sharma S, Rathored J, Ghosh B and Sharma SK (2010). Genetic polymorphisms in TNF genes and tuberculosis in North Indians. BMC Infect. Dis. 10: 165.

Trajkov D, Trajchevska M, Arsov T, Petlichkovski A, et al. (2009). Association of 22 cytokine gene polymorphisms with tuberculosis in Macedonians. Indian J. Tuberc. 56: 117-131.

Varahram M, Farnia P, Nasiri MJ, Karahrudi MA, et al. (2014). Association of Mycobacterium tuberculosis lineages with IFN- $\gamma$ and $T N F$ - $\alpha$ gene polymorphisms among pulmonary tuberculosis patient. Mediterr. J. Hematol. Infect. Dis. 6: e2014015.

Vejbaesya S, Chierakul N, Luangtrakool P and Sermduangprateep C (2007). NRAMP1 and TNF-alpha polymorphisms and susceptibility to tuberculosis in Thais. Respirology 12: 202-206.

Wilson AG, Symons JA, McDowell TL, McDevitt HO, et al. (1997). Effects of a polymorphism in the human tumor necrosis factor alpha promoter on transcriptional activation. Proc. Natl. Acad. Sci. U. S. A. 94: 3195-3199. 